Article

\title{
Chemical Composition, Antioxidant and Cytotoxicity Activities of Leaves, Bark, Twigs and Oleo-Resin of Dipterocarpus alatus
}

\author{
Chawalit Yongram ${ }^{1}$, Bunleu Sungthong ${ }^{2}\left(\mathcal{O}\right.$, Ploenthip Puthongking ${ }^{3, *} \mathbb{C}$ and \\ Natthida Weerapreeyakul ${ }^{3}$ \\ 1 Biomedical Science Program, Graduate School, Khon Kaen University, Khon Kaen 40002, Thailand \\ 2 Pharmaceutical Chemistry and Natural Products Research Unit, Faculty of Pharmacy, Mahasarakham \\ University, Mahasarakham 44150, Thailand \\ 3 Division of Pharmaceutical Chemistry, Faculty of Pharmaceutical Sciences, Khon Kaen University, \\ Khon Kaen 40002, Thailand \\ * Correspondence: pploenthip@kku.ac.th; Tel.: +66-4320-2378
}

Received: 31 July 2019; Accepted: 24 August 2019; Published: 25 August 2019

\begin{abstract}
Dipterocarpus alatus (Dipterocarpaceae) is a medicinal plant whose use is well known for the treatment of genito-urinary diseases. However, there is no report of its cytotoxic potential. In this study, the chemical composition, antioxidant and cytotoxic activities of extracts of the leaves, bark, twigs and oleo-resin from D. alatus are investigated. Cytotoxicity was measured by the neutral red (NR) assay against HCT116, SKLU1, SK-MEL2, SiHa and U937 cancer cell lines and antioxidant capacity was evaluated by DPPH, ABTS radical scavenging, and ferric reducing antioxidant power (FRAP) assays. The chemical composition was analyzed by gas chromatography-mass spectrometry (GC-MS). Leaf, bark and twig extracts exhibited stronger antioxidant activity than oleo-resin, with bark extract showing the highest antioxidant activity and the highest total phenolic content. All samples showed more cytotoxic activity against the U937 cell line than HCT116, SKLU1, SK-MEL2 and SiHa cells with oleo-resin being more cytotoxic than melphalan against U937 cells. Chemical composition analysis of oleo-resin by GC-MS showed that the major components were sesquiterpenes, namely $\alpha$-gurjunene (30.31\%), (-)-isoledene (13.69\%), alloaromadendrene (3.28\%), $\beta$-caryophyllene (3.14\%), $\gamma$-gurjunene (3.14\%) and spathulenol (1.11\%). The cytotoxic activity of oleo-resin can be attributed to the sesquiterpene content, whereas the cytotoxic and antioxidant activities of leaf, bark and twig extracts correlated to total phenolic content.
\end{abstract}

Keywords: anticancer; antioxidant; polyphenol; sesquiterpenes; GC-MS analysis; Dipterocarpus

\section{Introduction}

The most common incidences of cancer in Thailand are breast, cervix, colorectal, liver and lung cancers which made up $59.2 \%$ of the cancer burden in 2012, including $4 \%$ for the incidence of leukemia [1] and $4 \%$ incidence of melanoma which is mostly responsible for skin cancer [2]. Nowadays, cancer treatment is very costly, requiring expensive facilities, highly specialized health personnel and expensive drugs. Various approaches have been used for cancer treatment in addition to chemotherapy such as allopathic drugs for chemoprevention [3]. Moreover, chemotherapy generally leads to drug resistance and severe side effects [4]. Between 1940 and 2002, about $40 \%$ of all available anticancer drugs were natural products or natural products derived with $8 \%$ of those considered natural product mimics [5]. Thus, medicinal plants have made a tremendous contribution to the development of new drugs against diseases, including cancer [6]. 
Plants of genus Dipterocarpus have been reported to have many bioactivities including antibacterial, antioxidant [7], cytotoxic [8], anti-inflammatory [9] and anti-filarial activities [10]. Extracts of the bark and leaves of D. turbinatus used in Ayurvedic and Unani medicines showed potent cytotoxic activity against breast cancer cell lines [11]. The phytochemical constituent of plant genus Dipterocarpus produces a high yield of resveratrol oligomers (oligosilbenoids) [12], sesquiterpenes and triterpenes [13]. Ursolic acid, corosolic acid and isofouquierone triterpenes isolated from stems of D. obtusifolius showed cytotoxic activity against HepG2 and SK-OV-3 cancer cells at levels higher than chemotherapy Adriamycin [8]. Resveratrol oligomers isolated from the bark of $D$. hasseltii, inhibited murine leukemia P-388 cells, with hopeaphenol showing the strongest cytotoxic activity [14]. Vaticaffinol, a resveratrol oligomer isolated from $D$. alatus twigs and branches, reduced levels of serum uric acid and showed anti-inflammatory activity [15] while hopeahainol A and the oligostilbenoid, dipterocarpol A isolated from $D$. alatus stems exhibited acetylcholinesterase inhibitory activity [16].

The ethnomedicinal applications of $D$. alatus include the treatment of genitourinary diseases using oleo-resin [17] and D. alatus bark has been used in the treatment of liver diseases and rheumatism [18], to invigorate health, expel impurities and mitigate toothache [19] and to treat various skin diseases [20]. D. alatus balsam has been used for the treatment of gonorrhea and young D. alatus plants have been used to treat rheumatism and liver complaints [21]. However, there has been no report on the antioxidant and anticancer activity of $D$. alatus and the chemical composition has not been fully elucidated. The primary aim of the present work is to investigate the potential anticancer and antioxidant activities of various plant parts of $D$. alatus and subsequently the chemical characterization of the given parts using gas chromatography-mass spectrometry (GC-MS) in an effort to underline the correlation between chemical content and biological activity.

\section{Results and Discussion}

\subsection{Extraction and Phytochemical Analysis}

Different parts of D. alatus, like leaves, twigs and bark were macerated with methanol to yield extracts weighing $153.48 \mathrm{~g}(11.80 \%$ yield), $115.41 \mathrm{~g}(6.07 \%)$ and $29.68 \mathrm{~g}(4.24 \%)$, respectively. The qualitative phytochemical screening was carried out to identify the presence of secondary metabolites including alkaloids, steroids, tannins, xanthones, and reducing sugars (Table 1). Tannins and reducing sugars were found in leaf, bark and twig extracts. Alkaloids and xanthones were found only in bark, while steroids were found in bark, twigs and oleo-resin.

Table 1. Phytochemical screening of D. alatus extracts.

\begin{tabular}{cccccc}
\hline \multirow{2}{*}{ Part of Plant } & \multicolumn{5}{c}{ Chemical Group } \\
\cline { 2 - 6 } & Alkaloid & Steroid & Tannin & Xanthone & Reducing Sugar \\
\hline Leaves & - & - & + & - & + \\
Bark & + & + & + & + & + \\
Twigs & - & + & + & - & + \\
Oleo-resin & - & + & - & - & - \\
\hline
\end{tabular}

Presence (+) and absence (-).

\subsection{Chemical Constituents of D. alatus Extracts}

The major bioactive secondary metabolite of plants in the genus Dipterocapus is sesquiterpenoid essential oil containing sesquiterpenes as its major component [22]. Therefore, we characterized the secondary metabolites from the various parts of $D$. alatus by GC-MS. The oleo-resin elution profile identified 20 compounds (Table 2) and the six major compounds are summarized in Figure 1. Compounds 1-18 were identified to be members of the sesquiterpene family and compounds 19-20 were from the triterpene family. The six most abundant compounds were all sesquiterpenes with $\alpha$-gurjunene as the major component, comprising $30.31 \%$ of the total, followed by (-)-isoledene $(13.69 \%)$, 
alloaromadendrene (3.28\%), $\beta$-caryophyllene (3.14\%), $\gamma$-gurjunene (3.14\%) and spathulenol (1.11\%). While $\alpha$-gurjunene has previously been reported to be the major sesquiterpene component of $D$. hasseltii $(36.00 \%)$, D. intricatus $(80.00 \%)$ and D. kerrii $(79.17 \%)$, it is a minor component in D. retusus $(2.00 \%)$ and absent from D. grandifloras $[22,23]$. Sesquiterpenes and triterpenes were not detected in the D. alatus leaf and bark extracts, but a small amount $(0.05 \%)$ of the triterpene loupenone was found in twig extracts.
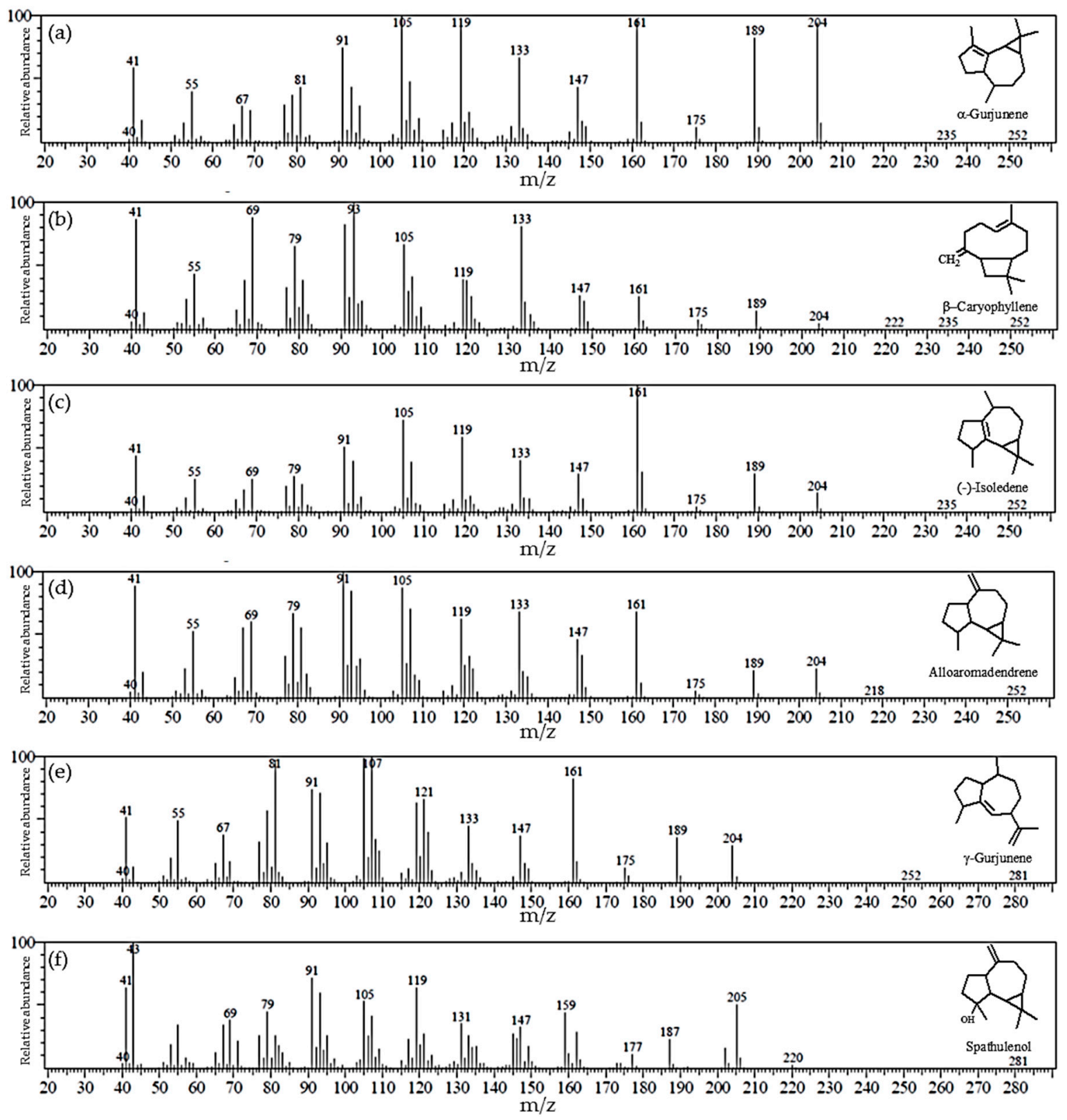

Figure 1. Gas chromatography-mass spectrometry (GC-MS) spectra of the major sesquiterpenes in oleo-resin. (a) $\alpha$-Gurjunene; (b) (-)-isoledene; (c) alloaromadendrene; (d) $\beta$-caryophyllene; (e) $\gamma$-gurjunene; and (f) spathulenol. 
Table 2. Principal compound profiling of oleo-resin of D. alatus by GC-MS.

\begin{tabular}{|c|c|c|c|c|c|c|}
\hline Compound & $\begin{array}{l}\text { Retention } \\
\text { Time }\end{array}$ & Compound Name & $\begin{array}{l}\text { Molecular } \\
\text { Weight }\end{array}$ & $\begin{array}{l}\text { Molecular } \\
\text { Formula }\end{array}$ & $\begin{array}{c}\% \text { (Peak } \\
\text { area) }\end{array}$ & Fragmentation Pattern $m / z$ (Decreasing Order of Abundance) \\
\hline 1 & 23.48 & $\delta$-Elemene & 204 & $\mathrm{C}_{15} \mathrm{H}_{24}$ & 0.08 & $121(100), 93,136,107,79,41,161,55,67,189,204$ \\
\hline 2 & 24.05 & $\alpha$-Cubebene & 204 & $\mathrm{C}_{15} \mathrm{H}_{24}$ & 0.03 & $105(100), 119,161,91,81,41,55,204,133$ \\
\hline 3 & 25.25 & $\alpha$-Copeane & 204 & $\mathrm{C}_{15} \mathrm{H}_{24}$ & 0.35 & $119(100), 105,161,93,81,41,55,133,204,65$ \\
\hline 4 & 25.98 & $\beta$-Elemene & 204 & $\mathrm{C}_{15} \mathrm{H}_{24}$ & 0.78 & 93(100), 81, 68, 107, 41, 55, 121, 147, 133, 161, 189, 175, 204 \\
\hline 5 & 26.87 & $\alpha$-Gurjunene & 204 & $\mathrm{C}_{15} \mathrm{H}_{24}$ & 30.31 & $105(100), 119,161,204,189,91,133,41,147,81,55,67$ \\
\hline 6 & 27.10 & $\beta$-Caryophyllene & 204 & $\mathrm{C}_{15} \mathrm{H}_{24}$ & 3.14 & $93(100), 69,41,133,105,79,55,119,147,161,189,175,204$ \\
\hline 7 & 27.63 & (-)-Isoledene & 204 & $\mathrm{C}_{15} \mathrm{H}_{24}$ & 13.69 & $161(100), 105,119,91,41,133,189,147,69,69,55,204$ \\
\hline 8 & 28.26 & $\alpha$-Humulene & 204 & $\mathrm{C}_{15} \mathrm{H}_{24}$ & 0.94 & $93(100), 80,121,41,147,107,67,55,204,136$ \\
\hline 9 & 28.55 & Alloaromadendrene & 204 & $\mathrm{C}_{15} \mathrm{H}_{24}$ & 3.28 & $91(100), 41,105,161,133,79,119,65,55,147,204,189$ \\
\hline 10 & 28.94 & $\gamma$-Gurjunene & 204 & $\mathrm{C}_{15} \mathrm{H}_{24}$ & 3.14 & $107(100), 81,161,91,121,41,55,133,67,189,147,204,175$ \\
\hline 11 & 29.65 & Viridiflorene & 204 & $\mathrm{C}_{15} \mathrm{H}_{24}$ & 0.61 & $107(100), 93,41,119,81,133,55,161,189,67,147,204,175$ \\
\hline 12 & 29.96 & $\beta$-Vatirenene & 202 & $\mathrm{C}_{15} \mathrm{H}_{22}$ & 0.12 & $145(100), 105,131,91,202,120,159,187,41,77,55,67,173$ \\
\hline 13 & 30.37 & Selina-3,7(11)-diene & 204 & $\mathrm{C}_{15} \mathrm{H}_{24}$ & 0.52 & $122(100), 161,107,91,81,41,55,67,133,204,189,147$ \\
\hline 14 & 31.65 & Calarene epoxide & 220 & $\mathrm{C}_{15} \mathrm{H}_{24} \mathrm{O}$ & 0.04 & $41(100), 65,93,109,119,82,135,161,185,145,177,205,220$ \\
\hline 15 & 31.85 & Palustrol & 222 & $\mathrm{C}_{15} \mathrm{H}_{26} \mathrm{O}$ & 0.13 & $122(100), 111,81,93,41,67,161,147,189,204,133,175,222$ \\
\hline 16 & 32.17 & Spathulenol & 220 & $\mathrm{C}_{15} \mathrm{H}_{24} \mathrm{O}$ & 1.11 & $43(100), 91,119,41,105,205,79,159,69,131,147,187,177,220$ \\
\hline 17 & 32.30 & $\begin{array}{l}\text { (-)-Caryophyllene } \\
\text { oxide }\end{array}$ & 220 & $\mathrm{C}_{15} \mathrm{H}_{24} \mathrm{O}$ & 0.75 & 41(100), 79, 93, 69, 109, 121, 131, 161, 187, 177 202, 220 \\
\hline 18 & 33.88 & $\alpha$-Cadinol & 222 & $\mathrm{C}_{15} \mathrm{H}_{26} \mathrm{O}$ & 0.08 & $95(100), 43,121,161,109,204,71,58,41,179,222$ \\
\hline 19 & 61.78 & Otochilone & 424 & $\mathrm{C}_{30} \mathrm{H}_{48} \mathrm{O}$ & 0.17 & $\begin{array}{c}409(100), 65,109,257,95,55,41,311,81,149,119,271,245,297,231 \\
173,161,204,187,424\end{array}$ \\
\hline 20 & 62.68 & Lupenone & 424 & $\mathrm{C}_{30} \mathrm{H}_{48} \mathrm{O}$ & 0.38 & $\begin{array}{c}95(100), 109,205,81,55,121,69,135,149,189,41,161,175,424,128, \\
313,245,355\end{array}$ \\
\hline
\end{tabular}




\subsection{Cytotoxic Activity}

The cytotoxicity of the leaf, bark and twig extracts and oleo-resin exhibited similar results in all cancer cell lines. All $D$. alatus samples showed high cytotoxic activity against the U937 cell line. $\mathrm{IC}_{50}$ values of $91.3 \pm 6.2$ (leaf), $106.1 \pm 7.8$ (bark), $128.9 \pm 2.5$ (twig), and $63.3 \pm 2.1 \mu \mathrm{g} / \mathrm{mL}$ (oleo-resin) were lower than the $\mathrm{IC}_{50}$ value for standard anticancer melphalan $(228.4 \pm 8.8 \mu \mathrm{g} / \mathrm{mL})$ in Table 3 . Oleo-resin showed cytotoxic activity against the HCT116, SK-LU-1, SK-MEL-2 and SiHa cell lines, but the $\mathrm{IC}_{50}$ values for oleo-resin were always higher than those for melphalan. In contrast, leaf and twig extracts showed little cytotoxic activity against the HCT116, SK-LU-1, SK-MEL-2 and SiHa cell lines and bark extract showed only moderate cytotoxicity against the SK-LU-1 and SiHa cell lines. However, oleo-resin was toxic to normal Vero cells $\left(\mathrm{IC}_{50} 88.7 \pm 4.1 \mu \mathrm{g} / \mathrm{mL}\right.$ ), while leaf, bark and twig extracts did not exert any toxic effect to normal Vero cells. The chemotherapy sensitivity and treatment outcomes of any tested compounds can be varied between differing tumor cell types. Taken together, these results indicate that the $D$. alatus leaf, bark and twig extracts have high selective cytotoxic activity against U937 cells with selective index (SI) values of 5.5, 4.7 and 3.9, respectively (Table 4). A selective index value higher than three in this case indicates high selectivity for cancer cells [24]. While the oleo-resin showed high toxicity to U937 cells, its cytotoxic selectivity (SI 1.4) is only moderate due to its toxicity to normal Vero cells. The cytotoxicity of oleo-resin against U937 might be related to its sesquiterpene chemical composition as (-)-isoledene has been shown to have cytotoxic activity against HCT 116 [25], alloaromadendrene has been shown to have antiproliferative activity against the highly malignant +SA mouse mammary epithelial cell line [26], $\beta$-caryophyllene exhibited cytotoxic activity against HCT 116 cells via apoptosis cell death pathway [27], and spathulenol showed antiproliferative activity against MCF-7, OVCAR-3 and HaCaT cells [28]. This finding suggests that compounds which belong to sesquiterpenes composition in oleo-resin of $D$. alatus are responsible for the anticancer properties.

Table 3. Cytotoxic activity of D. alatus extracts against several cancer cells.

\begin{tabular}{|c|c|c|c|c|c|c|}
\hline \multirow{2}{*}{ Samples } & \multicolumn{6}{|c|}{$\mathrm{IC}_{50}(\mu \mathrm{g} / \mathrm{mL})$} \\
\hline & Vero & HCT116 & SK-LU-1 & SK-MEL-2 & SiHa & U937 \\
\hline Leaves & $>500^{c}$ & $>500^{d}$ & $>500^{d}$ & $>500^{c}$ & $>500^{d}$ & $91.3 \pm 6.2^{b}$ \\
\hline Bark & $>500^{c}$ & $>500^{d}$ & $273.0 \pm 18.3^{b}$ & $>500^{c}$ & $197.8 \pm 15.5^{c}$ & $106.1 \pm 7.8^{\mathrm{c}}$ \\
\hline Twigs & $>500^{c}$ & $440.6 \pm 28.7^{c}$ & $>500^{d}$ & $>500^{c}$ & $>500^{\mathrm{d}}$ & $128.9 \pm 2.5^{\mathrm{d}}$ \\
\hline Oleo-resin & $88.7 \pm 4.1^{\mathrm{a}}$ & $340.3 \pm 21.1^{b}$ & $336.6 \pm 6.7^{c}$ & $215.2 \pm 10.9^{b}$ & $59.6 \pm 1.7^{b}$ & $63.3 \pm 2.1^{\mathrm{a}}$ \\
\hline Melphalan & $215.6 \pm 3.7^{b}$ & $179.6 \pm 12.2^{a}$ & $56.9 \pm 0.3^{\mathrm{a}}$ & $20.2 \pm 2.1^{\mathrm{a}}$ & $27.1 \pm 0.8^{a}$ & $228.4 \pm 8.8^{\mathrm{e}}$ \\
\hline
\end{tabular}

Table 4. Selective index of D. alatus leaf, bark and twig extracts, and oleo-resin.

\begin{tabular}{cccccc}
\hline \multirow{2}{*}{ Samples } & \multicolumn{5}{c}{ Selective Index (SI) * } \\
\cline { 2 - 6 } & HCT116 & SK-LU-1 & SK-MEL-2 & SiHa & U937 \\
\hline Leaves & 1.0 & 1.0 & 1.0 & 1.0 & $>5.5$ \\
Bark & 1.0 & $>1.8$ & 1.0 & $>2.5$ & $>4.7$ \\
Twigs & $>1.1$ & 1.0 & 1.0 & 1.0 & $>3.9$ \\
Oleo-resin & 0.3 & 0.3 & 0.4 & 1.5 & 1.4 \\
Melphalan & 1.2 & 3.8 & 10.7 & 8.0 & 0.9 \\
\hline & $*$ SI as IC IC $_{5}$ value of normal cell/IC 50 value of cancer cell.
\end{tabular}

\subsection{Antioxidant Activities and Total Phenolic Contents}

The radical scavenging activities of the $D$. alatus extracts and oleo-resin were evaluated using DPPH and ABTS radical scavenging assays and reducing power was determined using the ferric reducing antioxidant power (FRAP) assay. As shown in Table 5, the results from the DPPH and ABTS assays indicate no antioxidant activity for oleo-resin $\left(\mathrm{IC}_{50}>1000 \mu \mathrm{g} / \mathrm{mL}\right.$, both) while the bark extract 
showed similar radical scavenging capacity to Trolox $\left(\mathrm{IC}_{50} 5.76 \pm 0.19\right.$ and $9.37 \pm 0.03 \mu \mathrm{g} / \mathrm{mL}$ compared to $3.93 \pm 0.02$ and $10.20 \pm 0.10 \mu \mathrm{g} / \mathrm{mL}$, respectively). Extracts of twigs and leaves showed moderate radical scavenging activity (Table 5). The ferric reducing antioxidant power (FRAP) results show the extracts to have reducing power activity in the following order: barks $>$ leaves $>$ twigs $>$ oleo-resin, but all extracts had much lower reducing power activity than the standard antioxidant Trolox.

Table 5. Total phenolic content and radical scavenging activity of D. alatus leaf, bark and twig extracts, and oleo-resin.

\begin{tabular}{|c|c|c|c|c|}
\hline \multirow[b]{2}{*}{ Samples } & \multicolumn{3}{|c|}{ Antioxidant Capacity } & \multirow{2}{*}{$\begin{array}{l}\text { Total Phenolic Content } \\
\text { (mg GAE/g DW) }\end{array}$} \\
\hline & $\begin{array}{c}\mathrm{DPPH} \mathrm{IC}_{50} \\
(\mu \mathrm{g} / \mathrm{mL})\end{array}$ & $\begin{array}{c}\text { ABTS IC } 50 \\
(\mu \mathrm{g} / \mathrm{mL})\end{array}$ & $\begin{array}{c}\text { FRAP (mmole/100 } \\
\text { g DW) }\end{array}$ & \\
\hline Leaves & $26.76 \pm 0.25^{d}$ & $13.56 \pm 0.09^{c}$ & $124.80 \pm 0.19^{c}$ & $308.60 \pm 4.32^{b}$ \\
\hline Bark & $5.76 \pm 0.19^{b}$ & $9.37 \pm 0.03^{\mathrm{a}}$ & $300.67 \pm 2.93^{b}$ & $366.43 \pm 11.52^{a}$ \\
\hline Twigs & $16.53 \pm 0.61^{c}$ & $15.46 \pm 0.02^{d}$ & $102.79 \pm 1.01 \mathrm{~d}$ & $128.29 \pm 3.89^{c}$ \\
\hline Oleo-resin & $>1000^{\mathrm{e}}$ & $>1000{ }^{\mathrm{e}}$ & $21.02 \pm 0.19^{\mathrm{e}}$ & $15.14 \pm 0.62^{\mathrm{d}}$ \\
\hline Trolox & $3.93 \pm 0.02^{a}$ & $10.20 \pm 0.10^{b}$ & $771.70 \pm 11.37^{a}$ & - \\
\hline
\end{tabular}

Total phenolic contents (TPC) of crude extracts of D. alatus ranged from 15.14 to $366.43 \mathrm{mg}$ gallic acid equivalents (GAE) g/g DW. The bark extract showed the highest phenolic content (366.43 mg GAE/g DW) followed by leaves, twigs and oleo-resin, respectively (Table 5). These TPC results correlate with antioxidant activities, which might be related to the presence of tannin and reducing sugar groups in the extracts of barks, leaves and twigs.

\section{Materials and Methods}

\subsection{Plant Materials}

The leaves, twigs, bark and oleo-resin of D. alatus were collected from Khon Kaen province, Thailand during June 2014. The D. alatus was identified by Suppachai Tiyaworanant and a voucher specimen was deposited in the Division of Pharmacognosy and Toxicology, Faculty of Pharmaceutical Sciences, Khon Kaen University, under registration NO. PSKKF03682.

\subsection{Sample Preparation}

The leaves, twigs and bark of D. alatus were cut and mashed to dry powder (leaves $1300 \mathrm{~g}$, twigs $700 \mathrm{~g}$, and bark $1900 \mathrm{~g}$ ). The dry powder of each part was macerated with methanol for $24 \mathrm{~h}$ at room temperature and repeated three times. The combined organic solvent was removed after filtration and evaporated under reduced pressure followed by freeze drying to give crude extract. The oleo-resin crude was taken from the D. alatus tree. The sample was heated with temperature from $40-60{ }^{\circ} \mathrm{C}$ before use.

\subsection{Phytochemical Test}

The crude extracts of $D$. alatus were screened for the presence of tannins, xanthones, steroids, alkaloids and reducing sugars according to methods modified from Sasidharan et al. and Manosroi et al. [29,30]. Briefly, $30 \mathrm{mg}$ of crude extract was dissolved in $2 \mathrm{~mL}$ of ethanol and $2 \mathrm{~mL}$ of $15 \% \mathrm{FeCl}_{3}$ was added to the supernatant. Development of a blue-black or dark green color indicated tannins were present. For xanthones, $30 \mathrm{mg}$ of crude extract was dissolved in $2 \mathrm{~mL}$ of ethanol. Following centrifugation, $100 \mu \mathrm{L}$ of $5 \% \mathrm{KOH}$ was added to the supernatant and the presence of xanthones was observed by the development of a yellow precipitate. The presence of steroids was tested by adding 1 to 2 drops of conc. $\mathrm{H}_{2} \mathrm{SO}_{4}$ to $30 \mathrm{mg}$ of crude extract dissolved in $2 \mathrm{~mL}$ of chloroform. Steroids 
produced a red color in the lower chloroform layer. For alkaloids, $30 \mathrm{mg}$ of extract was dissolved in $1 \mathrm{~mL}$ of ethanol and mixed with $2 \mathrm{~mL} 1 \% \mathrm{HCl}$ and 6 drops of Dragendorff's reagent. A reddish-brown precipitate with turbidity indicated that alkaloids were present. For reducing sugars, $30 \mathrm{mg}$ of crude extract was mixed with $1 \mathrm{~mL}$ Fehling's solution. The mixture was heated in a water bath for $10 \mathrm{~min}$. The presence of reducing sugars was observed as a brick-red precipitate.

\subsection{Antioxidant Activity}

\subsubsection{DPPH Radical Scavenging}

The DPPH assay was modified from Ghasemzadeh et al. [31]. DPPH was dissolved in ethanol at a concentration of $200 \mu \mathrm{M}$. The $10 \mathrm{mg} / \mathrm{mL}$ stock solution of crude extract was prepared in $\mathrm{MeOH}$. Crude extract solution at $10-500 \mu \mathrm{g} / \mathrm{mL}$ and $200 \mu \mathrm{M}$ DPPH $(100 \mu \mathrm{L}$ each) were added into 96-well plates. The mixture was incubated at room temperature for $30 \mathrm{~min}$ in the dark. After incubation, absorbance was read at $490 \mathrm{~nm}$ using a microplate reader (Sunrise ${ }^{\mathrm{TM}}$, Grödig, Austria). The $\mathrm{IC}_{50}$ describes the concentration that causes half-maximal inhibition by the extract. Trolox was used as the positive control.

\subsubsection{ABTS Radical Scavenging}

This assay was modified from Kim et al. [32]. The ABTS radical cation was prepared by mixing $28 \mathrm{mM}$ ABTS with potassium persulfate $(2.45 \mathrm{mM})$ in purified water. The ABTS reagent was kept at room temperature in the dark for $18 \mathrm{~h}$ before use. The ABTS $(150 \mu \mathrm{L})$ was mixed with crude extract at $10-500 \mu \mathrm{g} / \mathrm{mL}(50 \mu \mathrm{L})$ in $96-$-well plates. Absorbance of the mixtures was read at $415 \mathrm{~nm}$ using a microplate reader and the $\mathrm{IC}_{50}$ was determined. Trolox was used as the positive control.

\subsubsection{Ferric Reducing Antioxidant Power (FRAP)}

A mixture of $300 \mathrm{mM}$ acetate buffer $\mathrm{pH} 3.6,20 \mathrm{mM} \mathrm{FeCl}_{3}$ solution and $10 \mathrm{mM}$ TPTZ in $40 \mathrm{mM}$ $\mathrm{HCl}$ in the ratio of 10:1:1 was prepared for the FRAP reagent. Crude extracts at $500 \mu \mathrm{g} / \mathrm{mL}(10 \mu \mathrm{L})$ were mixed with ultrapure water $(30 \mu \mathrm{L})$ and FRAP reagent $(300 \mu \mathrm{L})$ in 96 -well plates and incubated at $37^{\circ} \mathrm{C}$ for $4 \mathrm{~min}$. The absorbance was read at $595 \mathrm{~nm}$ using a microplate reader. Trolox was used as the positive control. The FRAP is reported in (mmole)/100 $\mathrm{g}$ DW units. The assay was modified from Benzie and Strain [33].

\subsubsection{Total Phenolic Content (TPC)}

The total phenolic content of the D. alatus extracts were determined using the method of Kaisoon et al. [34]. Folin-Ciocalteu reagent was diluted 10-fold with distilled water before use. A $16 \mu \mathrm{L}$ aliquot of $500 \mu \mathrm{g} / \mathrm{mL}$ extract was mixed with $117 \mu \mathrm{L}$ of Folin-Ciocalteu reagent in 96-well plates at room temperature for $5 \mathrm{~min}$. Then, sodium carbonate $(60 \mathrm{~g} / \mathrm{L})$ solution was added. The absorbance was read at $700 \mathrm{~nm}$ using a microplate reader after incubation at room temperature for $90 \mathrm{~min}$. The total phenolic content is shown as gallic acid equivalents (mg GAE/g DW).

\subsection{Cell Culture}

The normal African green monkey kidney (Vero), human colon cancer (HCT116), melanoma (SK-MEL-2), lung adenocarcinoma (SK-LU-1) and cervix adenocarcinoma (SiHa) cell lines were cultured in Dulbecco's Modified Eagle Medium (DMEM) supplemented with 10\% fetal bovine serum (FBS). The human leukemic U937 cell line was cultured in RPMI 1640 medium with $10 \%$ FBS. The media were supplemented with $1 \%$ penicillin/streptomycin and cells were maintained at $37^{\circ} \mathrm{C}$ in $5 \%$ atmospheric $\mathrm{CO}_{2}$ humidified incubator. 


\subsection{Cytotoxic Activity}

The cytotoxic activity of the crude extracts was assessed using the neutral red (NR) assay. The exposure time was $24 \mathrm{~h}$. Briefly, cells were seeded in 96 -well plates $\left(3 \times 10^{5}\right.$ cells $/ \mathrm{mL}$ for Vero and HCT116; $4 \times 10^{5}$ cells/mL for SK-MEL-2, SK-LU-1 and SiHa, and $5 \times 10^{5}$ cells/mL for U937) and test samples at $10-500 \mu \mathrm{g} / \mathrm{mL}$ were added. After incubation under normal conditions for $24 \mathrm{~h}$, cells were washed with PBS and $50 \mu \mathrm{g} / \mathrm{mL}$ of NR solution was added and plates were incubated for a further $2 \mathrm{~h}$. Cells were washed again with PBS and $0.33 \% \mathrm{HCl}$ in isopropanol was added. The absorbance was measured using a microplate reader at $537 \mathrm{~nm}$ for NR and at $650 \mathrm{~nm}$ for a reference wavelength [35]. The $\mathrm{IC}_{50}$ was calculated from a plot of $\%$ cytotoxicity and sample concentration.

\subsection{Gas Chromatography-Mass Spectrometry (GC-MS) Analysis}

The oleo-resin of $D$. alatus was analyzed by GC-MS with a SHIMADZU QP-2010 instrument (Kyoto, Japan). The oleo-resin was injected into an Agilent J\&W VF-5ms column $(30 \mathrm{~m} \times 0.25 \mathrm{~mm}$, $0.25 \mu \mathrm{m}$, Santa clara, CA, USA). The temperature of the injector was set at $290^{\circ} \mathrm{C}$. The oven temperature was initially set at $60^{\circ} \mathrm{C}$ (hold time $3 \mathrm{~min}$ ), with gradual increases in temperature from 60 to $120^{\circ} \mathrm{C}$ $\left(3.0^{\circ} \mathrm{C} / \mathrm{min}\right.$, hold $\left.1 \mathrm{~min}\right)$, from 120 to $280^{\circ} \mathrm{C}\left(2{ }^{\circ} \mathrm{C} / \mathrm{min}\right.$, hold $\left.1 \mathrm{~min}\right)$, and from 280 to $300^{\circ} \mathrm{C}\left(10^{\circ} \mathrm{C} / \mathrm{min}\right.$, hold $2 \mathrm{~min}$ ). Column flow was $1 \mathrm{~mL} / \mathrm{min}$. Carrier gas was helium 5.5, ionization energy was $70 \mathrm{eV}$ and the split ratio was set to 1:30 after $45 \mathrm{~s}$. The peaks were analyzed based on GC retention time and mass spectral identity was by comparison to the library (NIST147.LIB and WILEY7.LIB) [36].

\subsection{Statistical Analysis}

The antioxidant and cytotoxicity assays were carried out in triplicate. The results are presented as mean \pm standard deviation. Statistical analysis was performed using SPSS 19.0 software (SPSS Inc., Chicago, IL, USA) for Windows. The results were analyzed using one-way analysis of variance ANOVA with Tukey's honest significant difference test for comparing mean significant differences between samples $(p<0.05)$.

\section{Conclusion}

In this study, extracts of $D$. alatus leaves, barks and twigs showed stronger antioxidant capacity than oleo-resin and this was correlated with total phenolic content. Moreover, the leaf, bark and twig extracts inhibited the U937 cancer cell line without affecting normal Vero cells. Oleo-resin showed high non-selective cytotoxic activity against all tested cell lines with higher activity against the U937 cancer cell line than melphalan. The cytotoxic activity of oleo-resin appeared to correlate with the presence of sesquiterpenes, and especially $\alpha$-gurjunene, which is found in abundance in its balsam. In contrast, the cytotoxic and antioxidant activities of leaf, bark and twig extracts appeared to be related to the presence of phenolic compounds. Thus, these D. alatus extracts are promising targets for drug development in cancer and as antioxidant agents.

Author Contributions: P.P. conceived and designed the work. N.W. performed the cytotoxicity analyses. B.S. performed the GC-MS analyses. C.Y. performed the experiments, analyzed the data and drafted the manuscript. Each author approved the final version of the manuscript of submission.

Funding: This research was funded by Plant Genetic Conservation Project under the royal initiative of Her Royal Highness Princess Maha Chakri Sirindhorn, the National Research Council of Thailand (NRCT; Fiscal year 2560), Khon Kaen University Research Fund (Fiscal years 2558, 2559), Khon Kaen University Research Fund targeted on Yang-Na (KKU-YN60-012) and Graduate Research Fund from Khon Kaen University-National Research Council of Thailand (KKU-NRCT (Graduate) 016/2560).

Acknowledgments: We would to thank Somporn Katekaew, Faculty of Science, Khon Kaen University for providing oleo-resin of D. alatus, the Graduate School and the Faculty of Pharmaceutical Sciences, Khon Kaen University for their facilities and Glenn Borlace, Faculty of Pharmaceutical Sciences, Khon Kaen University for assistance with English language.

Conflicts of Interest: The authors declare no conflicts of interest. 


\section{References}

1. Virani, S.; Bilheem, S.; Chansaard, W.; Chitapanarux, I.; Daoprasert, K.; Khuanchana, S.; Leklob, A.; Pongnikorn, D.; Rozek, L.S.; Siriarechakul, S.; et al. National and subnational population-based incidence of cancer in Thailand: Assessing Cancers with the Highest Burdens. Cancers 2017, 9, 108. [CrossRef] [PubMed]

2. de Silva, M.B.; Tencomnao, T. The protective effect of some Thai plants and their bioactive compounds in UV light-induced skin carcinogenesis. J. Photochem. Photobiol. B 2018, 185, 80-89. [CrossRef] [PubMed]

3. Tariq, A.; Mussarat, S.; Adnan, M. Review on ethnomedicinal, phytochemical and pharmacological evidence of Himalayan anticancer plants. J. Ethnopharmacol. 2015, 164, 96-119. [CrossRef] [PubMed]

4. Ma, W.D.; Zou, Y.P.; Wang, P.; Yao, X.H.; Sun, Y.; Duan, M.H.; Fu, Y.J.; Yu, B. Chimaphilin induces apoptosis in human breast cancer MCF-7 cells through a ROS-mediated mitochondrial pathway. Food Chem. Toxicol. 2014, 70, 1-8. [CrossRef] [PubMed]

5. Balunas, M.J.; Kinghorn, A.D. Drug discovery from medicinal plants. Life Sci. 2005, 78, 431-441. [CrossRef]

6. Seca, A.M.L.; Pinto, D.C.G.A. Plant secondary metabolites as anticancer agents: successes in clinical trials and therapeutic application. Int. J. Mol. Sci. 2018, 19, 263. [CrossRef] [PubMed]

7. Zuraida, W.; Zain, W.M.; Ahmat, N.; Norizan, N.H.; Ainaa, N.; Nazri, A.M. The evaluation of antioxidant, antibacterial and structural identification activity of trimer resveratrol from Malaysia's Dipterocarpaceae. Aust. J. Basic Appl. Sci. 2011, 5, 926-929.

8. Khiev, P.; Kwon, O.K.; Song, H.H.; Oh, S.R.; Ahn, K.S.; Lee, H.K.; Chin, Y.W. Cytotoxic terpenes from the stems of Dipterocarpus obtusifolius collected in Cambodia. Chem. Pharm. Bull. 2012, 60, 955-961. [CrossRef]

9. Yang, W.S.; Lee, B.H.; Kim, S.H.; Kim, H.G.; Yi, Y.S.; Htwe, K.M.; Kim, Y.D.; Yoon, K.D.; Hong, S.; Lee, W.S.; et al. Dipterocarpus tuberculatus ethanol extract strongly suppresses in vitro macrophage-mediated inflammatory responses and in vivo acute gastritis. J. Ethnopharmacol. 2013, 146, 873-880. [CrossRef]

10. Senathilake, K.S.; Karunanayake, E.H.; Samarakoon, S.R.; Tennekoon, K.H.; de Silva, E.D.; Adhikari, A. Oleanolic acid from antifilarial triterpene saponins of Dipterocarpus zeylanicus induces oxidative stress and apoptosis in filarial parasite Setaria digitata in vitro. Exp. Parasitol. 2017, 177, 13-21. [CrossRef]

11. Akter, R.; Uddin, S.J.; Grice, I.D.; Tiralongo, E. Cytotoxic activity screening of Bangladeshi medicinal plant extracts. J. Nat. Med. 2014, 68, 246-252. [CrossRef] [PubMed]

12. Ito, T.; Tanaka, T.; Iinuma, M.; Nakaya, K.; Takahashi, Y.; Sawa, R.; Murata, J.; Darnaed, D. Two new resveratrol (=5-[(1E)-2-(4-Hydroxyphenyl)ethenyl]benzene-1,3-diol) tetramers with a tetrahydrofuran ring from Dipterocarpus grandiflorus. Helv. Chim. Acta 2004, 87, 479-495. [CrossRef]

13. Bisset, N.G.; Diaz, M.A.; Ehret, C.; Ourisson, G.; Palmade, M.; Patil, F.; Pesnelle, P.; Streith, J. Etudes chimio-taxonomiques dans la famille des diptérocarpacées-II.: Constituants du genre Diptérocarpus gaertn. F. Essai de classification chimio-taxonomique. Phytochemistry 1966, 5, 865-880. [CrossRef]

14. Muhtadi; Hakim, E.H.; Juliawaty, L.D.; Syah, Y.M.; Achmad, S.A.; Latip, J.; Ghisalberti, E.L. Cytotoxic resveratrol oligomers from the tree bark of Dipterocarpus hasseltii. Fitoterapia 2006, 77, 550-555. [CrossRef] [PubMed]

15. Chen, Y.S.; Chen, C.J.; Yan, W.; Ge, H.M.; Kong, L.D. Anti-hyperuricemic and anti-inflammatory actions of vaticaffinol isolated from Dipterocarpus alatus in hyperuricemic mice. Chin. J. Nat. Med. 2017, 15, 330-340. [CrossRef]

16. Chen, C.J.; Jiang, R.; Wang, G.; Jiao, R.H.; Tancharoen, C.; Sudto, K.; Vajarothai, S.; Hannongbua, S.; Ge, H.M.; Tan, R.X. Oligostilbenoids with acetylcholinesterase inhibitory activity from Dipterocarpus alatus. Planta Med. 2014, 80, 1641-1646. [CrossRef] [PubMed]

17. Appanah, S.; Turnbull, J.M. A Review of Dipterocarps: Taxonomy, Ecology and Silviculture; Center for international forestry research: Bogor, Indonesia, 1998; pp. 189-191.

18. Aslam, M.S.; Ahmad, M.S.; Mamat, A.S. A phytochemical, ethnomedicinal and pharmacological review of genus Dipterocarpus. Int. J. Pharm. Pharm. Sci. 2015, 7, 27-38.

19. Wiart, C. Medicinal Plants of the Asia-Pacific: Drugs for the Future? World scientific publishing Co. Pte. Ltd.: Singapore, 2006; pp. 139-140.

20. Prasad, P.R.C. Ecological analysis of Dipterocarpaceae of north andaman forest. India J. Plant. Develop. 2011, 18, 135-149.

21. Karnick, C.R.; Hocking, G.M. Ethnobotanical records of drug plants described in valmiki ramayana and their uses in the ayurvedic system of medicine. Quart. J. Crude Drug Res. 1974, 13, 143-154. [CrossRef] 
22. Jantan, I.B. The essential oil of Dipterocarpus kerrii. J. Trop. For. Sci. 1988, 1, 11-15.

23. Messer, A.; McCormick, K.; Hagedorn, S.H.H.; Tumbel, F.; Meinwald, J. Defensive role of tropical tree resins: Antitermitic sesquiterpenes from Southeast Asian Dipterocarpaceae. J. Chem. Ecol. 1990, 16, 3333-3352. [CrossRef] [PubMed]

24. Bézivin, C.; Tomasi, S.; Lohézic-Le Dévéhat, F.; Boustie, J. Cytotoxic activity of some lichen extracts on murine and human cancer cell lines. Phytomedicine 2003, 10, 499-503. [CrossRef] [PubMed]

25. Asif, M.; Shafaei, A.; Jafari, S.F.; Mohamed, S.K.; Ezzat, M.O.; Abdul Majid, A.S.; Oon, C.E.; Petersen, S.H.; Kono, K.; Abdul Majid, A.M. Isoledene from Mesua ferrea oleo-gum resin induces apoptosis in HCT 116 cells through ROS-mediated modulation of multiple proteins in the apoptotic pathways: A mechanistic study. Toxicol. Lett. 2016, 257, 84-96. [CrossRef] [PubMed]

26. Sawant, S.S.; Youssef, D.T.A.; Sylvester, P.W.; Wali, V.; El Sayed, K.A. Antiproliferative Sesquiterpenes from the Red Sea Soft Coral Sarcophyton glaucum. Nat. Prod. Commun. 2007, 2, 1-3. [CrossRef]

27. Dahham, S.S.; Tabana, Y.M.; Iqbal, M.A.; Ahamed, M.B.; Ezzat, M.O.; Majid, A.S.; Majid, A.M. The Anticancer, Antioxidant and Antimicrobial Properties of the Sesquiterpene $\beta$-Caryophyllene from the Essential Oil of Aquilaria crassna. Molecules 2015, 20, 11808-11829. [CrossRef] [PubMed]

28. do Nascimento, K.F.; Moreira, F.M.F.; Alencar Santos, J.; Kassuya, C.A.L.; Croda, J.H.R.; Cardoso, C.A.L.; Vieira, M.D.C.; Góis Ruiz, A.L.T.; Ann Foglio, M.; de Carvalho, J.E.; et al. Antioxidant, anti-inflammatory, antiproliferative and antimycobacterial activities of the essential oil of Psidium guineense Sw. and spathulenol. J. Ethnopharmacol. 2018, 210, 351-358. [CrossRef]

29. Sasidharan, S.; Chen, Y.; Saravanan, D.; Sundram, K.M.; Yoga Latha, L. Extraction, isolation and characterization of bioactive compounds from plants' extracts. Afr. J. Tradit. Complement. Altern. Med. 2011, 8, 1-10. [CrossRef]

30. Manosroi, J.; Boonpisuttinant, K.; Manosroi, W.; Manosroi, A. Anti-proliferative activities on HeLa cancer cell line of Thai medicinal plant recipes selected from MANOSROI II database. J. Ethnopharmacol. 2012, 142, 422-431. [CrossRef]

31. Ghasemzadeh, A.; Jaafar, H.; Juraimi, A.; Tayebi-Meigooni, A. Comparative evaluation of different extraction techniques and solvents for the assay of phytochemicals and antioxidant activity of Hashemi Rice Bran. Molecules 2015, 20, 10822-10838. [CrossRef]

32. Kim, D.O.; Chun, O.K.; Kim, Y.J.; Moon, H.Y.; Lee, C.Y. Quantification of polyphenolics and their antioxidant capacity in fresh plums. J. Agric. Food Chem. 2003, 51, 6509-6515. [CrossRef]

33. Benzie, I.F.F.; Strain, J.J. The ferric reducing ability of plasma (FRAP) as a measure of "antioxidant power": The FRAP assay. Anal. Biochem. 1996, 239, 70-76. [CrossRef] [PubMed]

34. Kaisoon, O.; Siriamornpun, S.; Weerapreeyakul, N.; Meeso, N. Phenolic compounds and antioxidant activities of edible flowers from Thailand. J. Funct. Foods. 2011, 3, 88-99. [CrossRef]

35. Srisayam, M.; Weerapreeyakul, N.; Barusrux, S.; Tanthanuch, W.; Thumanu, K. Application of FTIR microspectroscopy for characterization of biomolecular changes in human melanoma cells treated by sesamol and kojic acid. J. Dermatol. Sci. 2014, 73, 241-250. [CrossRef] [PubMed]

36. Gelmini, F.; Beretta, G.; Anselmi, C.; Centini, M.; Magni, P.; Ruscica, M.; Cavalchini, A.; Maffei Facino, R. GC-MS profiling of the phytochemical constituents of the oleoresin from Copaifera langsdorffii Desf. and a preliminary in vivo evaluation of its antipsoriatic effect. Int. J. Pharm. 2013, 440, 170-178. [CrossRef] [PubMed]

Sample Availability: Samples of Dipterocarpus alatus extracts are available from the authors. 